\title{
The Effect of Glycosaminoglycan from Urechis unicinctus on the Protein $C$ system and Relevant Factors Expression of HUVECs
}

\author{
Ping Liu ${ }^{\mathrm{a}}$, Qingman Cui ${ }^{\mathrm{b}}$, Wanying Wang ${ }^{\mathrm{c}}$ and Chunying Yuan ${ }^{\mathrm{d}}$ \\ Tianjin Key Laboratory for Marine Chemistry and Resource, College of \\ Marine Science \& Engineering, Tianjin University of Science and \\ Technology, Tianjin 300457 \\ aemail:1119137886@qq.com, ${ }^{b}$ email: cqm80@163.com, ${ }^{c}$ email: \\ 362017475@qq.com, \\ demail: ycy201388@163.com
}

\begin{abstract}
.
The influence of glycosaminoglycan from Urechis unicinctus on the protein C system and relevant factors expression of human umbilical vein endothelial cells (HUVECs) were studied with enzyme linked immunosorbent and reverse transcript-polymerase chain reaction (RT-PCR). Results indicated that: glycosaminoglycan could significantly decrease content of activated protein C, activated protein $S$ in blood of rats $(P<0.05, P<0.01)$, significantly elevated content of activated protein $C$ inhibitor $(P<0.05, P<0.01)$, slightly increase the thrombomodulin level. Glycosaminoglycan could significantly reduce the expression of tissue factor gene, promote the expression of tissue factor pathway inhibitor and thrombomodulin gene $(P<0.01)$.

Keywords: Urechis unicinctus; Glycosaminoglycan; Protein C system; Umbilical vein endothelial cells; Gene expression
\end{abstract}

\section{Introduction}

A variety of glycosaminoglycans from scallop, Ruditapes philippinarum, Sinonovacula constrzcta, Stichopus japonicus, Scapharca subcrenata, Mactra veneriformism, Patinopecten yessoensism, Bullacta exarata and other marine animals had been extracted and isolated, and their functional activities had been studied[1-9]. Urechis unicinctus know as sea intestines, a long cylindrical mollusks, which have high medicinal and nutritional value [10]. Previous studies have shown that, glycosaminoglycan had good anticoagulant activity. Therefore the effct of glycosaminoglycan on protein $\mathrm{C}$ in rat and the expression of human 
umbilical vein endothelial cell tissue factor was conducted, in order to lay good foundation for the further utilization of glycosaminoglycan.

\section{Materials and Methods}

Glycosaminoglycan from Urechis unicinctus was separated and purified by Applied Marine Biology Laboratory, and the purity was 94.6\%; Specific pathogen free-level wister rats(weighted 201.3 \pm 11.6 g), were purchased from from the Laboratory Animal Center of the Military Medical Science Academy of the PLA, with the license number of SCXK-(Jun)2012-0004; HUVECs from the College of Bioengineering, Tianjin University of Science and Technology; Protein C Elisa kit was purchased from Beijing Solarbio Technology Co Ltd; DMEM-f12 was purchased from GIBCO company, CCK-8 was purchased from Tiangen Biochemical Technology Co., Ltd., RT-PCR related reagents were purchased from Invitrogen, TF, TFPI, TM and GAPDH primers by Huada Gene Technology Service Co., Ltd.

Main instruments included Multiskan GO Microplate Rreader and $370 \mathrm{CO}_{2}$ Incubator(Thermo Forma), CKX41-C31BF invert microscope(OLYMPUS), SmartSpec plus nucleic acid protein analyzer, T100 ${ }^{\mathrm{TM}}$ PCR and ChemiDoc XRS gel imager(Bio-Rad), DYY-6C gel electrophoresis(Beijing Liuyi Instrument Factory).

Effect of Glycosaminoglycan on the Protein C System in Rats. 30 rats were randomly divided into 5 groups. After normal feeding for 3 days, rats were administered with tail vein injection of $0.9 \%$ saline, heparin solution $(4 \mathrm{mg} / \mathrm{kg})$ and glycosaminoglycan $(1 \mathrm{mg} / \mathrm{kg}, 4 \mathrm{mg} / \mathrm{kg}, 16 \mathrm{mg} / \mathrm{kg}$ ) respectively, $30 \mathrm{~min}$ later, blood samples were withdrawn from arteria femoralis in rats and anticoagulated with sodium citrate $(9: 1, \mathrm{v} / \mathrm{v})$, and centrifuged at $3000 \mathrm{rpm} 20 \mathrm{~min}$, the serum was prepared. The concentration of APC, PS, TM and APCI were measured with Elisa kits.

Activity Determination of HUVECs. 6 block of 96 well plates were used, each plate was divided into 5 groups and each group was added into 6 holes with HUVECs $\left(1 \times 10^{6} \mathrm{ind} / \mathrm{L}\right)$. After the cells were cultured for $24 \mathrm{~h}$, culture medium 
was aspirated, then washed each well twice with 2\% DMEM-F12 which contained $2 \%$ bovine serum, then $100 \mu \mathrm{L}$ DMEM(containing the concentration of $0,0.25,1,4,16 \mathrm{mg} / \mathrm{mL}$ glycosaminoglycan respectively) was added into each hole. After 6, 12, 24, 36, 48, 72 h respectively, the culture medium was sucked out, and $100 \mu \mathrm{L}$ culture medium (no bovine serum) and $10 \mu \mathrm{L}$ CCK-8 were added into each hole. After $1 \mathrm{~h}$ incubation in incubator, the absorbance was measured at $450 \mathrm{~nm}$, activity of HUVECs was represented by absorbance value. the maximum concentrations of selected cell activity in the experiment. The concentration which activity of HUVECs was the largest was selected for subsequent experiments

Transcriptional Level Detection of TM, TF and TFPI mRNA by RT-PCR. Total RNA of HUVECs was extracted according to TRIzol kit instruction. Reverse transcription was conducted according to the Invitrogen RT-PCR kit instruction. Primer sequences of TM, TF, TFPI and GAPDH (Inner consult) were shown in Table 1.

$1 \%$ Agarose gel electrophoresis was conducted with $5 \mu \mathrm{L}$ PCR product, bands of marker were $600,500,400,300,200,100$ bp respectively. The electrophoresis results were scanned and analyzed using Image J software, and expression intensity of TF, TFPI and TM gene was expressed using area ratio of TF, TFPI and TM to GAPDH respectively.

Table 1 Primer sequences of TM, TF, TFPI and GAPDH

\begin{tabular}{llll}
\hline Primer & & Sequence $\left(5^{\prime} \rightarrow 3^{\prime}\right)$ & $\begin{array}{l}\text { Amplified } \\
\text { fragment length[bp] }\end{array}$ \\
& & & \\
& & & \\
TF & Upstream & GGATGTGAAGCAGACGTACT & 284 \\
& Downstream & GTGTAGAGATATAGCCAGGA & 218 \\
TFPI & Upstream & CAGTGCGAAGAATTTATATATGG & 400 \\
TM & Downstream & TTGCATTCTTCCAGTGTCTC & \\
& Upstream & CATGTGCGAGACCGGCTACCGGCTGGCGG & \\
GAPDH & Upstream & GTCAGTGGTGGACCTGACCT & \\
& Downstream & TGAGGAGGGGAGATTCAGTG & \\
\hline
\end{tabular}

Data Processing Statistics. All experimental data were analysed by single factor 
analysis of variance. Analysis software was SPSS 17.0, the experimental data were expressed in mean+SD.

\section{Results and Analysis}

Influence of Glycosaminoglycan on the Protein C System in Rats. The experimental results were shown in Table 1. Compared with the control group, heparin and glycosaminoglycan could significantly reduce the concentrationblood of APC and PS $(P<0.05, P<0.01)$, and had a certain concentration-dependent effect; heparin and high concentration of glycosaminoglycan could significantly increase APCI concentration $(P<0.05$, $P<0.01$ ); heparin and different concentrations of glycosaminoglycan could slightly increase TM concentrations. Compared with heparin, high concentration of glycosaminoglycan could significantly decrease APC concentration $(P<0.05)$.

Table 2 The effect of glycosaminoglycanon on protein $\mathrm{C}$ system in rats

\begin{tabular}{llllll}
\hline Groups & Control & $\begin{array}{l}\text { Heparin } \\
{[4 \mathrm{mg} / \mathrm{mL}]}\end{array}$ & $\begin{array}{l}\text { GAG } \\
{[1 \mathrm{mg} / \mathrm{mL}]}\end{array}$ & $\begin{array}{l}\text { GAG } \\
{[4 \mathrm{mg} / \mathrm{mL}]}\end{array}$ & $\begin{array}{l}\text { GAG } \\
{[16 \mathrm{mg} / \mathrm{mL}]}\end{array}$ \\
APC $[\mu \mathrm{g} / \mathrm{L}]$ & $2.665 \pm 0.216$ & $2.369 \pm 0.182^{*}$ & $2.261 \pm 0.187^{* *}$ & $2.204 \pm 0.189^{* *}$ & $2.094 \pm 0.166^{* * a}$ \\
PS[ $\mu \mathrm{g} / \mathrm{L}]$ & $8.999 \pm 0.649$ & $8.035 \pm 0.662^{*}$ & $7.954 \pm 0.616^{*}$ & $7.947 \pm 0.641^{*}$ & $7.886 \pm 0.575^{*}$ \\
$\mathrm{APCI}[\mathrm{mg} / \mathrm{L}]$ & $3.314 \pm 0.519$ & $3.944 \pm 0.382^{*}$ & $3.945 \pm 0.393^{*}$ & $4.065 \pm 0.409^{*}$ & $4.132 \pm 0.341^{* *}$ \\
TM[ng/mL] & $1.327 \pm 0.125$ & $1.366 \pm 0.112$ & $1.384 \pm 0.124$ & $1.399 \pm 0.112$ & $1.433 \pm 0.092$ \\
\hline
\end{tabular}

Note: compared with the control group, ${ }^{*} P<0.05$, ${ }^{* *} P<0.01$; compared with heparin group, ${ }^{\mathrm{a}} \mathrm{P}<0.05$

Effect of Glycosaminoglycan on the Activity of HUVECs. The results were shown in Table 3. The activity of HUVECs increased with the increase of glycosaminoglycan concentration, when the concentration of glycosaminoglycan reached $0.25 \mathrm{mg} / \mathrm{mL}$, the activity of HUVECs was the maximum.

Table 3 Effect of glycosaminoglycan on the activity of HUVEC cells

\begin{tabular}{llllll}
\hline Groups & 0 & $0.25[\mathrm{mg} / \mathrm{mL}]$ & $1[\mathrm{mg} / \mathrm{mL}]$ & $4[\mathrm{mg} / \mathrm{mL}]$ & $16[\mathrm{mg} / \mathrm{mL}]$ \\
$6[\mathrm{~h}]$ & $0.611 \pm 0.002$ & $0.923 \pm 0.006^{* *}$ & $0.822 \pm 0.005^{* *}$ & $0.623 \pm 0.009$ & $0.462 \pm 0.029^{* *}$ \\
$12[\mathrm{~h}]$ & $0.623 \pm 0.004$ & $0.957 \pm 0.005^{* *}$ & $0.842 \pm 0.011^{* *}$ & $0.638 \pm 0.006$ & $0.48 \pm 0.008^{* *}$ \\
$24[\mathrm{~h}]$ & $0.634 \pm 0.002$ & $1.126 \pm 0.007^{* *}$ & $0.961 \pm 0.007^{* *}$ & $0.655 \pm 0.011^{* *}$ & $0.453 \pm 0.002^{* *}$ \\
$36[\mathrm{~h}]$ & $0.669 \pm 0.009$ & $1.19 \pm 0.001^{* *}$ & $1.007 \pm 0.006^{* *}$ & $0.734 \pm 0.005^{* *}$ & $0.427 \pm 0.004^{* *}$ \\
$48[\mathrm{~h}]$ & $0.686 \pm 0.004$ & $1.111 \pm 0.001^{* *}$ & $0.953 \pm 0.008^{* *}$ & $0.693 \pm 0.006^{* *}$ & $0.413 \pm 0.005^{* *}$ \\
$72[\mathrm{~h}]$ & $0.627 \pm 0.001$ & $1.064 \pm 0.008^{* *}$ & $0.901 \pm 0.003^{* *}$ & $0.646 \pm 0.003^{* *}$ & $0.47 \pm 0.001^{* *}$ \\
\hline
\end{tabular}


Note: compared with the control group, ${ }^{*} P<0.05$, ${ }^{* *} P<0.01$

Effect of Glycosaminoglycan on TF, TFPI and TM Gene Expression in HUVECs. Agarose gel electrophoresis results were shown in Figure 1-3, Image $\mathrm{J}$ software analysis results were shown in Table $4.36 \mathrm{~h}$ reached a significant level $(\mathrm{P}<0.05)$, glycosaminoglycan can significantly enhance the TFPI gene expression was significant $(\mathrm{P}<0.05)$ at the time of $36 \mathrm{~h}$, glycosaminoglycan can significantly enhance the TM gene expression in $36 \mathrm{~h}$ is reached significant level $(\mathrm{P}<0.01)$.
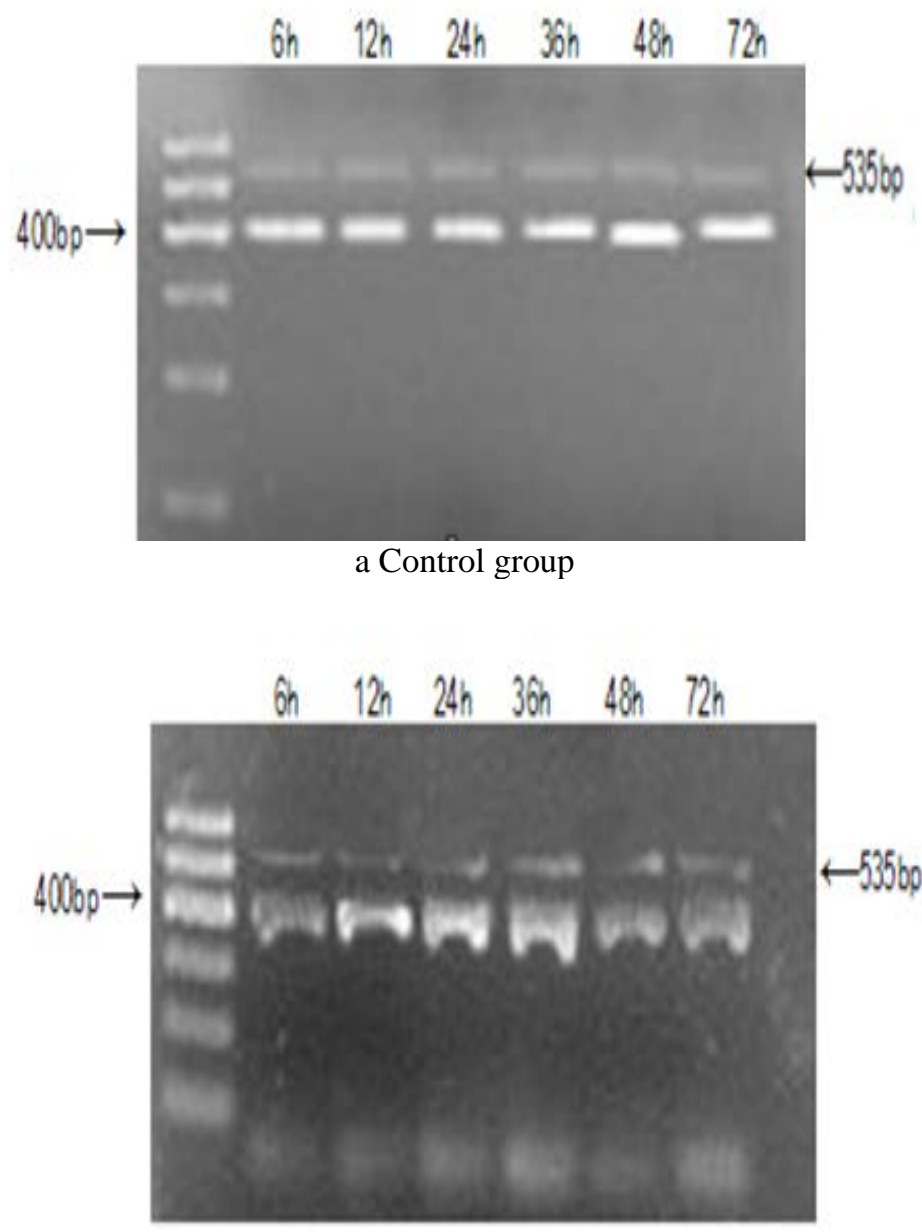

b Glycosaminoglycan group

Fig. 1 Effect of glycosaminoglycan on TF gene expression in HUVECs 

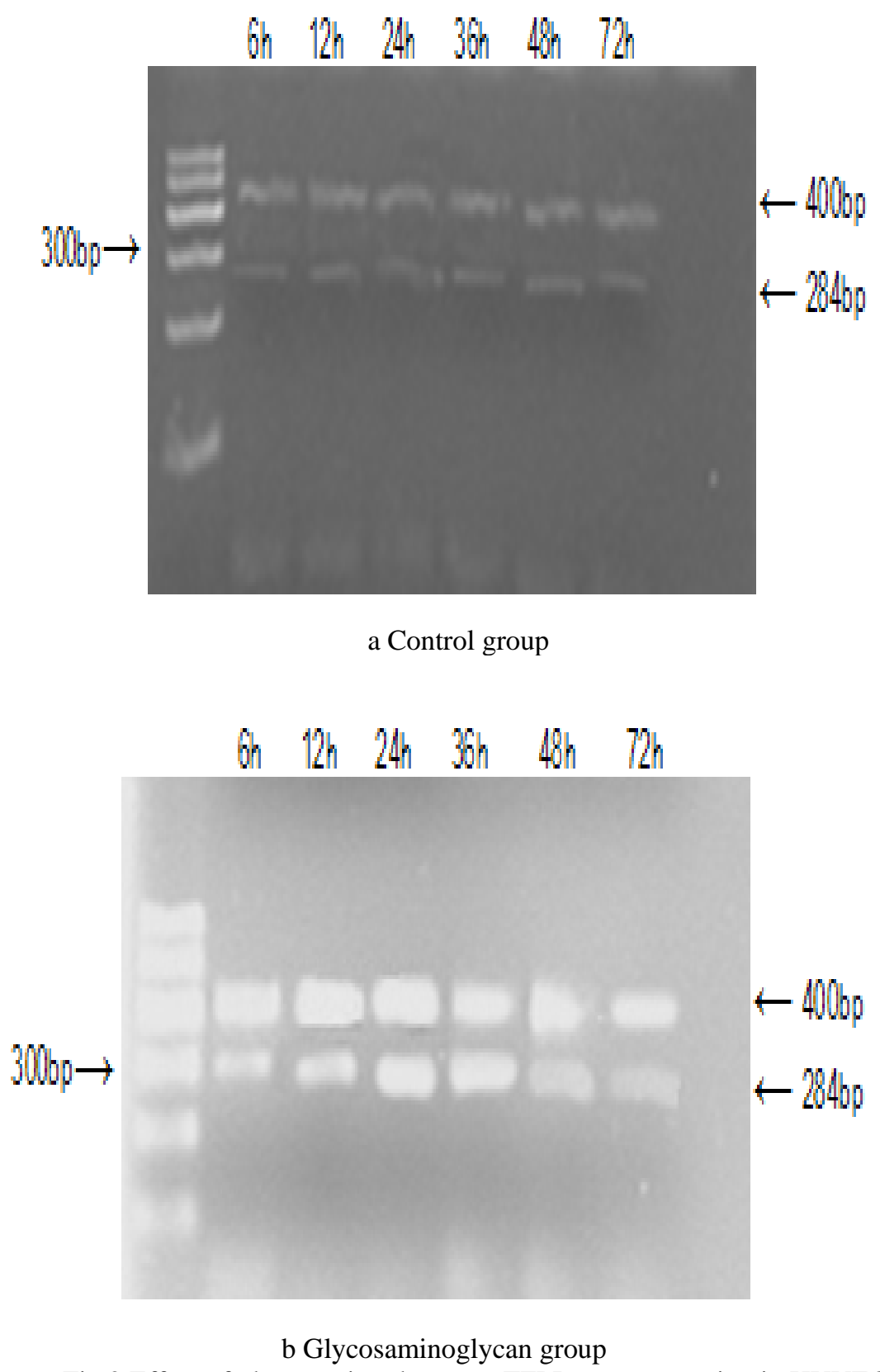

Fig 2 Effect of glycosaminoglycan on TFPI gene expression in HUVECs 


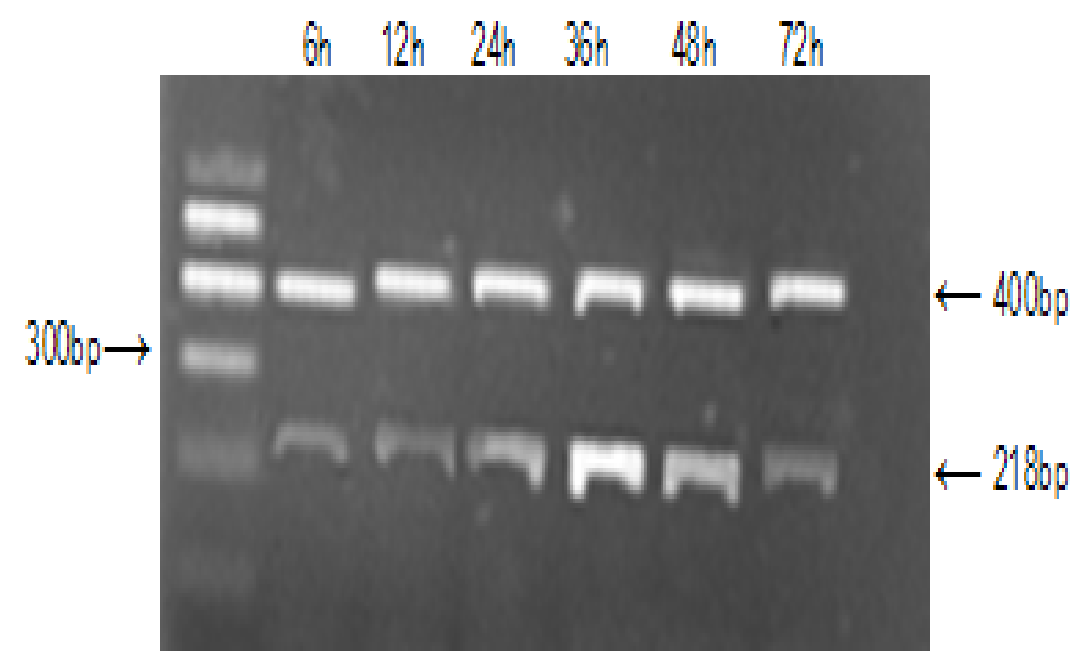

a Control group

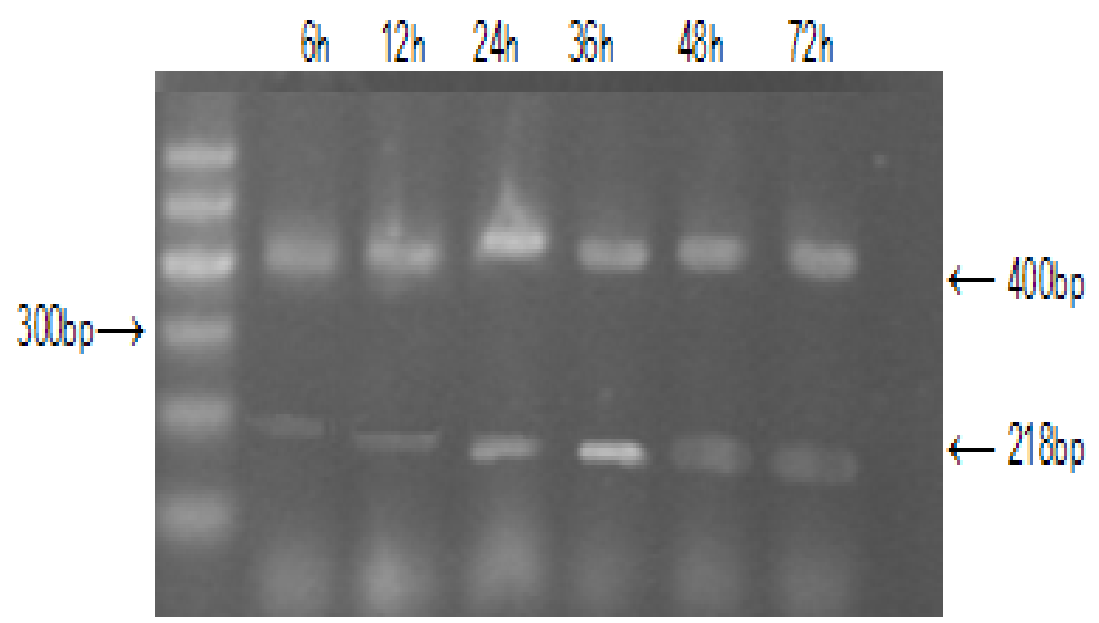

b Glycosaminoglycan group

Fig 3 Effect of glycosaminoglycan on TM gene expression in HUVECs

Table 4 Effect of Glycosaminoglycan on TF, TFPI and TM Gene Expression in $\operatorname{HUVECs}(\overline{\mathrm{X}} \pm \mathrm{SD}, \mathrm{n}=3)$

\begin{tabular}{lllllll}
\hline Time[h] & 6 & 12 & 24 & 36 & 48 & 72 \\
\hline Control $_{\mathrm{TF}}$ & $0.183 \pm 0.005$ & $0.192 \pm 0.005$ & $0.203 \pm 0.007$ & $0.22 \pm 0.006$ & $0.202 \pm 0.005$ & $0.189 \pm 0.007$ \\
GAG & $0.124 \pm 0.004^{* *}$ & $0.105 \pm 0.005^{* *}$ & $0.064 \pm 0.008^{* *}$ & $0.05 \pm 0.006^{* *}$ & $0.096 \pm 0.005^{* *}$ & $0.107 \pm 0.005^{* *}$ \\
Control $_{\text {TFPI }}$ & $0.195 \pm 0.005$ & $0.205 \pm 0.008$ & $0.216 \pm 0.003$ & $0.234 \pm 0.001$ & $0.223 \pm 0.003$ & $0.181 \pm 0.002$ \\
\hline
\end{tabular}




\begin{tabular}{lllllll}
\hline GAG & $0.162 \pm 0.002^{* *}$ & $0.323 \pm 0.001^{* *}$ & $0.501 \pm 0.002^{* *}$ & $0.503 \pm 0.003^{* *}$ & $0.189 \pm 0.003^{* *}$ & $0.172 \pm 0.002^{* *}$ \\
\hline Control & $0.441 \pm 0.005$ & $0.459 \pm 0.001$ & $0.476 \pm 0.009$ & $0.481 \pm 0.056$ & $0.448 \pm 0.005$ & $0.435 \pm 0.006$ \\
GAG & $0.221 \pm 0.007^{* *}$ & $0.242 \pm 0.003^{* *}$ & $0.675 \pm 0.011^{* *}$ & $1.931 \pm 0.03^{* *}$ & $0.874 \pm 0.001^{* *}$ & $0.49 \pm 0.006^{* *}$ \\
\hline
\end{tabular}

Note: compared with the control group, ${ }^{*} P<0.05$, ${ }^{* *} P<0.01$

\section{Conclusions}

Glycosaminoglycan from $U$. unicinctus had great influence on protein C system of rats; the glycosaminoglycan could obviously promote the activity of HUVECs, significantly decrease the expression level of TF gene, improve the expression levels of TFPI and TM gene.

\section{Acknowledgements}

This research was financially supported by Tianjin Application-based \& Cutting-edge Technology Research Plan (Grant NO. 13JCZDJC29600).

\section{References}

[1] N. Yu, S. Liu, J. J. Han, F. S Su: Acta Academiae Medicinae Qingdao Universitatis Vol. 44 (2008), p.111-113.

[2] R.F. Wang, H.M. Wu, X.P. Fan: Journal of Guangdong Ocean University Vol. 28 (2008), p.25-29.

[3] X.L. Lei, H.M. Wu, X.P. Fan, S.J. Zhao: Pharmaceutical Biotechnology Vol. 11 (2004), p. 146-149.

[4] Y. Kariya, S. Watanabe, Y. Ochriai, K. Murata: Comparative Biochemistry and Physiology Part

B: Comparative Biochemistry Vol. 95 (1990), p.387-392.

[5] H.X. Qiong, H.M. Wu: Z.M. Lin, X.P. Fan: Modern Food Science and Technology Vol. 24 (2008) , p.763-766.

[6] C.Y. Yuan, Q.M. Cui, H.F. Sun, X.P. Sun: Journal of Anhui Agri. Sci Vol. 39 (2011), p.5882-5884.

[7] H.L. Yin, Y. Ma, L. Wang, Y.M. Sun, Y.H. Yu, B.W. Zhu: Fisheries Science Vol. 26 (2007), p.255-258.

[8] J.L Xu, Q.M. Cui, C.Y. Yuan, Y.G. Wang, Y. Zhang, G.J. Li: Journal of Anhui Agri. Sci Vol. 40 (2012), p.3559-3561.

[9] C.Y. Yuan, Q. M. Cui, J. L. Xu, G. J. Li: Guangdong Agric Sci Vol.3(2013), p.173-175.

[10] Z. J. Liu, C. H. Zhang, X. Zhao, B. F. Li: Food Science Vol. 33(2012), p.37-40. 